This item was submitted to Loughborough's Research Repository by the author.

Items in Figshare are protected by copyright, with all rights reserved, unless otherwise indicated.

\title{
Network position and firm performance - The mediating role of innovation
}

PLEASE CITE THE PUBLISHED VERSION

http://dx.doi.org/10.1080/09537325.2016.1216095

\section{PUBLISHER}

(C) Taylor \& Francis

\section{VERSION}

AM (Accepted Manuscript)

\section{PUBLISHER STATEMENT}

This work is made available according to the conditions of the Creative Commons Attribution-NonCommercialNoDerivatives 4.0 International (CC BY-NC-ND 4.0) licence. Full details of this licence are available at: https://creativecommons.org/licenses/by-nc-nd/4.0/

\section{LICENCE}

CC BY-NC-ND 4.0

\section{REPOSITORY RECORD}

Dolfsma, Wilfred, and Rene Van der Eijk. 2019. "Network Position and Firm Performance - the Mediating Role of Innovation". figshare. https://hdl.handle.net/2134/22198. 


\section{Network Position and Firm Performance - The mediating role of innovation}

Key words: $\quad$ innovation, firm strategies, network position, performance

Abstract:

Analyzing a unique, domain-similar database including all

horticulturalists in a major flower producing country, this paper

shows that a firm's central position in a network significantly

improves its financial performance. The effect of strategic

positioning in a network is in large part mediated through its enhanced innovativeness. Strategically positioning in a network of firms contributes more to firm performance, both directly as well as indirectly, than other strategic options a firm has available, such as seeking scale, seeking to diversify, pursuing cost advantages, or locating in a cluster.

\section{Introduction}

Firms can adopt a number of strategies to improve their performance. Well-known, perhaps even classical strategies to adopt are being a cost leader, differentiating the products offered, and seeking scale. ${ }^{1}$ Studies in economic geography studies point to the positive effect of being located in a cluster, thus benefitting from knowledge spill-overs. More recently, the position of a firm in a network of other firms is claimed to have an impact on how it will perform in terms of a number of performance indicators (Dhanaraj and Parkhe 2006; Human and Provan 1997; Zaheer et al. 2010). For organizations,

\footnotetext{
${ }^{1}$ Modifying the quality of a product is a broadly recognized strategy a firm may chose that we cannot include for methodological reasons, as we will explain below.
} 
competing in a global market, innovation is argued to play an increasingly central role in their long term survival, especially in an industry where economic conditions seem to be relatively unfavorable, for instance in terms of labor costs and climate. Presumably, the strategic options firms have allow them to perform better (e.g., Ireland and Hitt 2005), partly because smart strategizing will make firms more innovative (Phelps 2010). Indeed, the importance of innovation for firm performance is often alluded to. The effect of strategies adopted by firm on financial performance is claimed to be a highly contingent one (Gulati et al. 2000; Liao and Rice 2010; Zaheer et al. 2010), however, and has not been empirically investigated before. In part this is due to data limitations, but in part this is due to the mediating effect of the strategies firms adopt on firm performance through enhanced innovativeness.

Doing exactly this, the paper contributes two important insights to the existing literature in strategic and innovation management. First of all we show that a firm's innovativeness is a mediating variable between firm strategies on the one hand and firm performance on the other hand. This insight is regularly invoked, and has seemed plausible, but has remained in need of substantive proof. Strategies that firms may adopt may enhance performance by allowing them to be more innovative. A second insight pertains more to the strategic management literature per se. This paper allows for a direct comparison of the effects of different strategies a firm might consider to improve performance, either directly or mediated through innovation. We find that, comparing a number of strategic options firms have, only strategically positioning in a network of firms (cf. Ireland and Hitt 2005; Ozcan and Eisenhardt 2009) contributes to firm performance, both directly as well as through a firm's enhanced innovativeness. Other, well-known strategic options, such as seeking scale, seeking to diversify products offered, pursuing cost advantages, or locating in a regional cluster do not improve firm performance.

Using a unique, domain-specific database of all major horticulturalists growing Freesia flowers in the Netherlands, a highly competitive and global knowledge-intensive industry, we determine if and to what extent financial performance is either directly determined by a set of strategic options that a firm has, or if the effect of strategies is 
mediated through a firm's enhanced innovativeness. In the mediation model (Figure 1) these are routes I and II respectively.

Figure 1: Research Framework

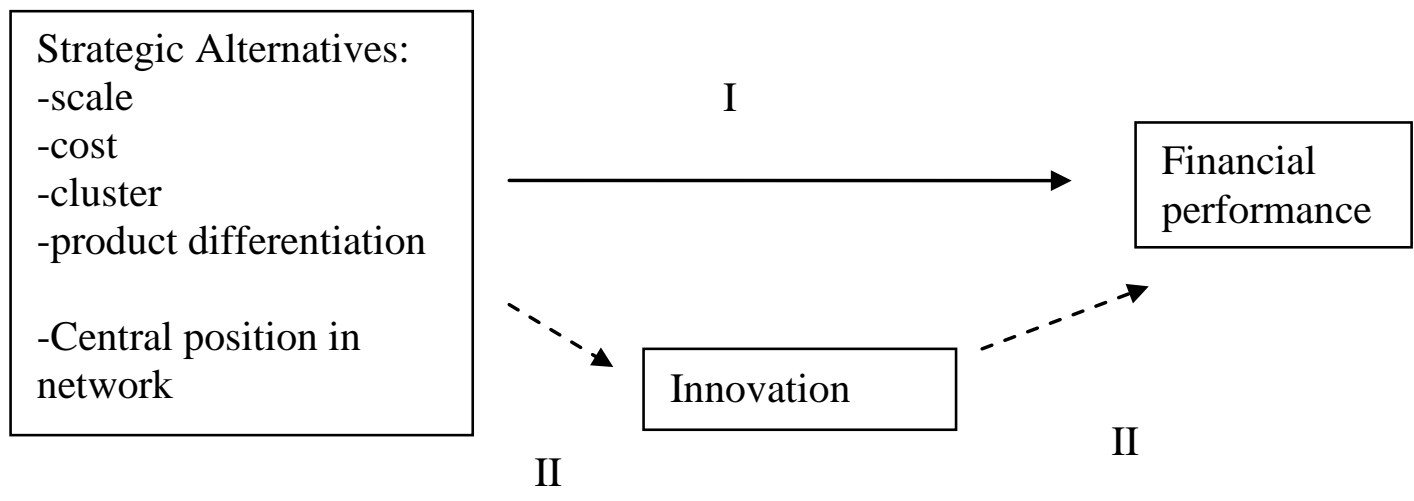

The paper first discusses the relevant literature relating to strategic choices a firm can make, including about its network position, innovativeness and firm performance. Section 3 discusses data and method, Section 4 presents our results, and Section 5 discusses some implications of the findings. Section 6 concludes.

\section{Networks, Innovation and Firm Performance}

The strategic choices that firms make affect their innovative performance and financial performance. Classical strategic choices that firms have include pursuing economies of scale, locating in an attractive region, differentiating one's products, and cost leadership. More recently, it has been argued that a firm's position in a network of relevant relations is a strategic variable for firms that it can change purposively and that can affect their performance (Ozcan \& Eisenhardt 2009; Giuliani \& Bell 2005). Thus being able to determine how a firm's (financial) performance is affected by a number of strategic options, possibly mediated by its innovativeness, allows for a much deeper insight in the issue of how innovation affects firm performance (cf. Geroski et al. 1993). The strategic choices can conceivably have a direct effect on firm performance, but may also indirectly 
contribute to firm performance by enhancing firm innovativeness (Giuliani and Bell 2005).

\subsection{Classic Strategies}

Ireland and Hitt (2005) discuss how a number of strategies may contribute to a firm's innovativeness and performance. A firm may perform well because it offers a range of products. Customers may be attracted to buying from such a firm rather than from a competitor. A diversified firm may more easily deal with risk and can also more easily exploit the possibilities arising from newly developed knowledge the application of which can be difficult to determine in advance and thus be more inclined to innovate (Granstrand et al. 1997). There can thus be scope economies in doing research. Alternatively, by being involved in the production of different products, a novel development in one area might be quite easily made use of or adopted for the use in the production of another. Scale of production may directly improve performance when scale economies hold: average costs per product are reduced as fixed costs are spread over a larger number of goods produced. In the Schumpeter Mark II tradition, scale is also believed to be beneficial to firms in allowing them to be more innovative as well (Malerba 1997). Large firms have more resources to invest in R\&D and are better at allowing researchers to develop specialized and cutting-edge knowledge. Scale economies might but need not arise from production, and so do not necessarily equate to strategic benefits resulting from cost leadership. How a firm's cost structure affects its performance and product innovativeness is unclear, particularly for the latter. High production cost, and particularly high fixed costs may be an entry barrier, reducing the number of competitors and leading to higher margins that could partly be used to innovate. High fixed costs may also make a firm more vulnerable for business cycle effects, lowering profitability. Facing high production costs relative to sales could leave little resources for investing into innovative activities. Alternatively, however, Kleinknecht \& Vergeer (2010) argue that higher costs can force firms to innovate such that the costly production factor is used more efficiently. Geographically locating close to where other, similar firms are located so a cluster is formed will attract specialized suppliers of intermediary goods and of labor, and specific sales facilities. Competition 
between suppliers will lead to a situation where they offer a more attractive price-quality choice than had otherwise been the case. Differentiation by these related firms may allow a firm to obtain the offering that best fits with its own strategic choice. Firms located in a cluster may benefit from knowledge spill-overs and thus be more innovative (Frenken et al. 2014; Van der Panne 2004; Arkhan 2009).

\subsection{Network Position as Strategic Option}

Positioning in a network of relevant firms is increasingly seen as an important strategic option for firms (Belderbos et al. 2004; Ozcan \& Eisenhardt 2009). Others have researched what the effect of contacts and cooperation with third parties on innovativeness or firm performance is (e.g., Belderbos et al. 2004), ${ }^{2}$ without, however, taking into account how the focal firm structurally relates to these third parties. A favorable position in a network can allow a firm to use the information it is thus able to gather strategically in negotiating with other firms. It may also be able to define the architecture of an industry, establishing the rules that firms willingly or unintentionally adopt that may favor some firms over others in terms of financial performance.

Network position and characteristics are known to impact firm performance directly (Ingram and Roberts 2000; Reagans and McEvily 2003; Reagans and Zuckerman 2001; Tsai 2001). Network position and characteristics can, for instance, allow a firm to gain information about market opportunities for its own products as well as about competitors' product portfolio and their strategic maneuvering (Dittrich and Duysters 2007). Network position and characteristics can thus allow the firm to make better use of the resources at its disposal which would improve financial performance.

Ties are channels for information and resource flows (Beckman and Haunschild 2002; Tsai and Ghosal 1998). Social networks are not only relevant for identifying problems and opportunities, but, maybe even more importantly, allow for the identification of potentially valuable innovative technologies and solutions (Ozcan \& Eisenhardt 2009; Gulati and Higgins 2003; Kijkuit and van den Ende, 2007; Oh et al.

\footnotetext{
${ }^{2}$ Belderbos et al. (2004) use data from the Community Innovation Survey (CIS). While CIS data has a number of advantages, it has disadvantages too (cf. Kleinknecht et al. 2002). Firms with fewer than 10 employees, for instance, are not surveyed, thus significantly underestimating innovative activity (Dolfsma \& Van der Panne 2008).
} 
2006). Being centrally located in a network stimulates innovation by actors - both for individuals and for firms. A firm that has more connections receives more relevant information about developments in the market and technological developments. Social network literature holds that while knowledge may reside in actors, it is through networks that knowledge is exchanged and can be both put to use and developed further (Allen 1977; Tushman 1977; Tushman and Scalan 1981; Coleman et al. 1996). Central positions within networks are associated with several benefits such as influence and information advantages (Burt 1992; Hansen 1999; Uzzi 1997; Reagans and McEvily 2003; Granovetter, 1973; Tsai, 2001). Centrally located actors in a network are more likely to be innovative (Ibarra 1993; Sparrowe et al. 2001; Wasserman and Faust 1994). This holds for firms too (Phelps 2010). Being centrally positioned an actor receives information and insights from many others (Brass 1984), including political and emotional resources (Oh et al. 2006). As resources and information tend to gravitate towards the center of the network, a centrally located actor is shown to be more innovative and to perform better financially (Tsai 2001). The literature suggests that a centrally located actor in a network will also receive more diverse information which promotes knowledge exchange and innovation (Freeman 1991; Lundval 1988). Diversity of input may refer not only to differences in the knowledge base (Beckman and Haunschild 2002; Gilsing et al 2008), but also to different competencies (Phelps 2010; Reagans and McEvily 2003; Rodan and Galunic 2004).

An ultimate goal of (financial) performance might then be reached through an intermediate goal of innovativeness. Being well-positioned in a (diverse) network can provide a firm with information advantages that allow a firm to innovate itself or be aware of innovations by others that can be adopted (Ahuja 2000; Giuliani and Bell 2005; Geroski et al. 1993). Well networked firms are thus likely to perform better, financially, in part by being more innovative (Ingram and Roberts 2000; Sparrowe et al. 2001). A firm's location in a network might thus have both a direct effect on firm financial performance, as well as have a mediated impact on firm financial performance through firm innovativeness.

Ours is the first study to include a comprehensive set of strategic options that a firm has at its disposal to behave strategically in order to improve its position, 
distinguishing between direct and indirect effects, quantitatively. The rich nature of our data also allows us to separate the effects of different strategic options that firms have on firm performance. Some of these are well established in the literature - we refer to these only tangentially.

\section{Method and Data}

Horticulture. ${ }^{3}$ This study performs a social network analysis at the inter-firm level in a domain-specific setting offering products to a global market. A focus on a specific setting prevents extraneous variation from affecting the findings. A cross-sectional study would allow for industry specific effects to influence findings. Relevant factors affecting firm strategy can also more easily be identified and precisely measured in a domain-similar study, at least in part overcoming the endogeneity problem (Shaver 1998).

Ever since the tulip mania in $17^{\text {th }}$ Century Netherlands, this country and production of flowers have become synonymous in many people’s minds. In actual fact, on a small area that comprises no more than $2 \%$ of the total area used to grow flowers worldwide, in terms of value produced the Netherlands is the second largest player worldwide producing just under $15 \%$ of the total produce, while in terms of export value over 50\% emanates from the Netherlands. With a total export value of 6 billion euro in 2006, flowers and plants are a significant economic factor in the Netherlands. The Dutch horticulture is responsible for 40 percent of the total agricultural production in the Netherlands. Much of the production, often in glass houses, in the over 2700 firms, is concentrated in the densely populated south-western parts of the country, close to the sea. This is the so-called Westland region. In addition to cut-flowers, pot flowers and bulbs are produced. Within the flower production industry the Freesia flower is one of the ten commercially most important products with a turnover of 55.4 million euro in 2006. The value chain for horticulture in general and also for Freesia flowers is short - no processing is required, for instance. Dutch horticulturalists are efficient and innovative. They need to be, as they face a huge cost of production disadvantage compared to other producers. The focus in this industry is on efficiency and timeliness of production. For

\footnotetext{
${ }^{3}$ This section partly draws from Snijders et al. (2007).
} 
this reason, the kind of focal innovation focused on is appropriate (see Appendix). The government instigated Innovation Platform has identified flowers as an important focal point for the Dutch economy (Innovatieplatform 2004). In developing product and process innovations, close cooperation with research institutes and universities is sought by the sector as a collectivity through what can be called 'study groups'. The flower auctions, established in the late $19^{\text {th }}$ and early $20^{\text {th }}$ Century, are cooperatives as well.

Data collection. The unique nature of the data and its focus on a specific domain-similar setting (Human and Provan 1997), only make this study conducive to network analysis if network boundaries can readily be specified and a high response rate can be obtained (Marsden 2002). Some studies have adopted a social network approach, but included in their analysis a relatively small sample from among relevant players (Giuliani and Bell 2005) and thus have seen the analysis one is able to perform compromised - see Wasserman \& Faust (1994) for further discussion of relevant methodological considerations. Network data was obtained by interviewing horticulturalists for whom Freesias is a substantial part of production. Some horticulturalists chose not to participate, or the data about them was incomplete. In our analysis we use data for 63 of a total of 70 horticulturalists that comprise the full sample, which means that we include $90 \%$ of the full sample of horticulturalists. Costenbader \& Valente (2003) argue that this is a much higher percentage than is required when using the network measure we employ (degree centrality; see below).

Data was collected from a number of different sources. Data collection started at the Dutch auction houses. ${ }^{4}$ Freesia flowers can be traded on a daily basis at the auction. We obtained sales data on all separate transactions by active flower growers for whom Freesias were the main product. Auction data indicated that 70 firms reported substantial revenues from freesia sales. ${ }^{5}$ A full list of horticulturalists is available as well from the branch organization and through industry experts. Triangulation between these sources prevented oversight of horticulturalists and provides evidence of a clear network

\footnotetext{
4 The Floraholland and Aalsmeer auctions are among the world's largest flower auctions. Flowers from across the world (Europe, Colombia, Ethiopia, etc) are traded on a daily basis. The auction houses merged January $1^{\text {st }}, 2008$.

${ }^{5}$ Interviews with growers with a revenue below $€ 100,000$ from Freesia flowers indicated that these growers focus primarily on growing other crop, indicating that information on them is a-typical.
} 
boundary (Marsden 2002). Information about the price for the ground on which the horticulturalists are located, as an indicator of a firm's cost structure, was obtained from the Dutch Land Registry Office (called "Kadaster"). We have obtained additional data and insights from industry experts, especially about the key innovation in the sector.

\section{Variables.}

As our ultimate dependent variable performance variable we use turn-over for 2007. ${ }^{6}$ As a measure for the mediating variable, innovation, we use a process innovation, or a new means of producing the goods a firm produced all along, but somehow in a better way. We focus on a technology to regulate ground temperature (see Appendix A for a description). The technology has been identified by industry experts as the innovation that substantially impacts the business in the focal industry, allowing for both production volumes and quality of the products to increase substantially. As in most cases of innovation, this innovation is developed outside of the sector (Dolfsma and Van der Panne 2008; Geroski 1993) - the innovation thus is not new to the world, but it is new to the industry and to the firm. Taking a single innovation allows for better comparison as, statistically, noise is reduced. The innovation can be introduced in 9 distinctive steps which we measured each. The innovation index allots a constant value for the introduction for each phase minus a penalty for each year the firm was late introducing the innovation. The innovation index includes all phases and accounts for the respective year of introduction. We prefer to use this more objective measure for innovativeness in the analysis we present, rather than the self-reported extent to which producers claim to be innovative. Both these measures provide similar results, however.

The centrality measure for a firm's network position is determined by asking each respondent to list their key industry contacts ['Over the past 6 months are there any work related contacts from whom you regularly sought (research related) information and advice to enhance your effectiveness as an entrepreneur? Who are your most valued work contacts']. Note that we identified all horticulturalists for whom growing freesia flowers

\footnotetext{
${ }^{6}$ The strategic options that firms can employ may result in both higher financial performance, but could also show in higher average price per product sold. We have used this alternative dependent variable in a separate analysis. The results of this analysis, which are mostly similar with weaker model-fit indicators, are available upon request from the authors.
} 
is the most important commercial activity, and were able to obtain complete data for 90 per cent of the full relevant population. We use degree centrality (Aalbers \& Dolfsma 2015; Scott 1991; Wasserman and Faust 1994), the number of ties ego maintains in a network, since it provides a comprehensive and most readily interpretable indication of the network structure of an actor and ascertains an actor's prominence in a network structure (Balkundi and Harrison, 2006; Bono and Anderson, 2005; Brass, 1984; Cross and Cummings, 2004; Freeman, 1979; Mehra et al., 2001). While we did not require that the contact corroborate a tie, we did check whether this self-reported measure generated reliable data as we collected data in the full network and with industry experts (cf. Sparrowe et al. 2001). The presence of asymmetric relationships, representing nonreciprocated ties, may be expected between prominent and less prominent network actors (Knoke and Burt 1983). Centrally located individuals may not mention all alters they in actual fact do relate with.

We include a number of variables in our analysis that strategic management literature suggest should impact either performance or innovativeness. These could be strategic alternatives employed by firms to improve its competitive position. Firm Size (1), providing scale economies, is measured as square meters of the production facility. Other Crop (2), hinting at economies of scope or the choice between either diversification or specialization, is a dichotomous variable where 1 represents "other crop" and 0 "no other crop". The variable for Cluster (3) is a dichotomous variable were 1 indicates being located in a cluster and (0) denotes a location outside a cluster. In addition to the well-known Westland cluster, four additional clusters were identified Venlo, Boskoop, Duin en Bollenstreek, and Aalsmeer - to better separate the regional effect of close proximity from the network effect of availability of a tie. Alternative specifications for this cluster variable, for instance distance to flower auction house claimed as an important competitive advantage (Snijders et al. 2007, p.32), provided similar results to the ones presented. For production Cost (4) the proxy used is the price for a hectare of land that zone planning allows to be used to construct a glass house on in a narrowly defined region where the horticulturalist is located. We used information from the Dutch Land Registry Office (Kadaster), the branch organization, and from the survey as sources. 
Number of Company Owners is included as a control variable. Presence of multiple company owners might affect (delay) strategic decisions from being taken and implemented as strategic focus may be lost, but it might also improve the quality of the decisions. Age, another control variable included, is the age of the (principal) entrepreneur, in years. We used information from the survey to establish this.

Testing. We conduct a hierarchical regression analysis based on ordinary least squares to determine if the effect of network position and characteristics on firm performance is (partially) mediated by innovativeness (Baron and Kenny (1986). The Appendix provides descriptive statistics. Table 1 presents regression coefficients (betas), absolute value of tstatistics, R-squares and Adjusted R-squares. In addition, F-test values for changes in Rsquare when new variables are included. Models 1 and 2 test the direct route (I; Figure 1), taking financial performance as a dependent variable. Control variables and wellrecognized variables indicating a firm's strategic discretionary choice were entered on the first step (Model 1). Network centrality (in-degree) enters in the second step (Model 2). The Innovation index was the dependent variable in models 3 and 4 . Model 3 only has the control and classical strategy variables, and the network variable enters in model 4 in order to test for partial mediation along route II (Figure 1). The indirect route of mediation was finalized by subsequently including the Innovation index as an independent variable in the third step along with the control variables the classical strategic variables and the centrality variable (Model 5). A Sobel (1982) test is used to determine if the mediation found is statistically significant. In addition, VIF scores were calculated to determine if multicollinearity is an issue. No VIF score, in any of the models in Table 1, was higher than 1.506. This is well below any commonly held, conservative upper bound beyond which multicollinearity is believed to be indicated

\section{Results}

As is to be expected, in this highly competitive, global sector, costs negatively impacts performance (Model 1: $\mathrm{B}=-0.26, \mathrm{p}<0.05$; Model 3: $\mathrm{B}=-0.23, \mathrm{p}<0.05$ ), but the effect becomes statistically insignificant when a firm's network position is taken into account. A very similar story holds for geographic positioning in a cluster, albeit that the effect is 
to stimulate innovation (Model 1: $\mathrm{B}=0.275, \mathrm{p}<0.05$; Model 3: $\mathrm{B}=0.234, \mathrm{p} .<0.05$ ). One network position enters, the Beta soon becomes less significant (Model 2), or insignificant (models 4 and 5).

Model 2 considers the impact of network structure on financial performance. Network centrality is positively related with a firm's financial performance $(B=0.465$, $\mathrm{p}<0.01$ ). Network centrality also ensures that firms are more innovative (Model 4: $\mathrm{B}=$ 0.308, $\mathrm{p}<0.05$ ). Subsequently, network centrality positively affects a firm’s financial performance (see Model 5: $\mathrm{B}=0.347, \mathrm{p}<0.01$ ). We thus find that a central position offers significant advantages (Dhanaraj and Parkhe 2006; Human and Provan 1997).

To test for partial mediation, we conducted a 3 stage analysis to determine whether the three conditions for mediation are satisfied (Baron and Kenny 1986). Models 1 and 2 permit a test of the first condition for mediation, which is that there is an effect to be mediated. This is the case. Models 3 and 4 permit a test of the second condition, which is that the mediator is predicted by the independent variables. This also holds true. Model 5 presents the results of the hierarchical regression analysis testing the third condition for mediation, which is to include the independent and the mediating variable in a final model. Including the mediating variable Innovativeness significantly increases the explained variance of the model.

Table 1: $\quad$ Firm Performance and Innovativeness

\begin{tabular}{|c|c|c|c|c|c|}
\hline \multirow[t]{2}{*}{ Dependent Vars.: } & \multicolumn{2}{|c|}{$\begin{array}{c}\text { Mediation } \\
\text { Base Model } \text { Step } 1 \\
\text { Revenue }\end{array}$} & \multicolumn{2}{|c|}{$\begin{array}{l}\text { Mediation } \\
\text { step } 2 \\
\text { Innovation }\end{array}$} & \multirow{2}{*}{$\begin{array}{c}\text { Mediation } \\
\text { step } 3 \\
\text { Revenue } \\
\text { Model } 5\end{array}$} \\
\hline & Model 1 & Model 2 & Model 3 & Model 4 & \\
\hline $\begin{array}{l}\text { Independent Vars.: } \\
\text { Controls }\end{array}$ & & & & & \\
\hline Age & $\begin{array}{l}-0.275^{* *} \\
(-0.275)\end{array}$ & $\begin{array}{l}-0.182 * \\
(-1.694)\end{array}$ & $\begin{array}{c}0.004 \\
(0.033)\end{array}$ & $\begin{array}{c}0.066 \\
(0.569)\end{array}$ & $\begin{array}{l}-0.207^{* *} \\
(-2.09)\end{array}$ \\
\hline $\begin{array}{l}\text { Governance (\# Company } \\
\text { owners) }\end{array}$ & $\begin{array}{c}0.067 \\
(0.561)\end{array}$ & $\begin{array}{l}0.04 \\
(0.374)\end{array}$ & $\begin{array}{l}0.04 \\
(0.339)\end{array}$ & $\begin{array}{c}0.022 \\
(0.197)\end{array}$ & $\begin{array}{c}0.031 \\
(0.319)\end{array}$ \\
\hline $\begin{array}{l}\text { Strategic Alternatives } \\
\text { Diversification }\end{array}$ & 0.118 & 0.021 & 0.13 & 0.066 & -0.004 \\
\hline
\end{tabular}




\begin{tabular}{|c|c|c|c|c|c|}
\hline & $(1.03)$ & $(0.201)$ & (1.136) & $(0.585)$ & $(-0.043)$ \\
\hline Scale & $\begin{array}{c}0.187 \\
(1.536)\end{array}$ & $\begin{array}{c}0.051 \\
(0.451)\end{array}$ & $\begin{array}{l}\text { 0.393*** } \\
(3.228)\end{array}$ & $\begin{array}{l}0.303 * * \\
(2.476)\end{array}$ & $\begin{array}{c}-0.065 \\
(-0.587)\end{array}$ \\
\hline Cost & $\begin{array}{l}-0.26 * * \\
(-2.251)\end{array}$ & $\begin{array}{l}-0.162 \\
(-1.526)\end{array}$ & $\begin{array}{l}-0.23 * * \\
(-1.989)\end{array}$ & $\begin{array}{c}-0.165 \\
(-1.445)\end{array}$ & $\begin{array}{c}-0.099 \\
(-0.995)\end{array}$ \\
\hline Cluster (1=cluster) & $\begin{array}{l}0.275^{* *} \\
(2.365)\end{array}$ & $\begin{array}{c}0.18 * \\
(1.688)\end{array}$ & $\begin{array}{l}0.234^{* *} \\
(2.018)\end{array}$ & $\begin{array}{l}0.172 \\
(1.5)\end{array}$ & $\begin{array}{c}0.114 \\
(1.143)\end{array}$ \\
\hline \multicolumn{6}{|l|}{ Network } \\
\hline Network entrality & & $\begin{array}{l}0.465^{* * *} \\
(3.984)\end{array}$ & & $\begin{array}{c}0.308 * \star \\
(2.458)\end{array}$ & $\begin{array}{l}0.347^{* * *} \\
(3.077)\end{array}$ \\
\hline Innovation & & & & & \\
\hline Innovation & & & $x$ & $x$ & $\begin{array}{l}0.383^{* * *} \\
(3.406)\end{array}$ \\
\hline $\mathrm{R}^{2}$ & 0.261 & 0.42 & 0.263 & 0.332 & 0.518 \\
\hline Adj. $R^{2}$ & 0.168 & 0.350 & 0.188 & 0.252 & 0.45 \\
\hline Overall F & 3.469 & 15.872 & 3.507 & 6.043 & 11.603 \\
\hline df. & 59 & 58 & 59 & 58 & \\
\hline
\end{tabular}

Notes: 2-tailed; t-values in parentheses; ${ }^{*},{ }^{* *},{ }^{* * *}$ correlation is significant at the $0.10,0.05,0.01$ level.

For full mediation the contribution of the independent variables signifying Strategic Alternatives, Controls and Network on the dependent variable of Performance must become insignificant after the mediating variable is introduced in the final mediation step 3. This is true for most independent variables but not for all: the betas for network position (centrality) and age remain non-zero and significant. Adding the mediator variable innovativeness in model 5 adds 19.8 percent to the explained variance of firm performance compared with model 4. A Sobel test to determine if the mediation by a firm's innovativeness on its performance indeed is statistically significant indeed shows that it is $(\mathrm{z}=1.988 ; \mathrm{p}<0.05$; Sobel 1982). These results indicate that the innovative capacity partially mediates the effects of network structure on financial performance. There is a direct and a mediated effect from network position (centrality) to firm performance - the mediated effect is through increased firm innovativeness. 
Innovative capacity was significantly related to firm financial performance (B = 0.383, $\mathrm{p}<0.01)$. Network centrality also stayed significant although Beta and significance level both decreased for model 5 when compared with model $2(B=0.461[p<0.01]$ and respectively $B=0.349[\mathrm{p}<0.05])$.

\section{Discussion}

A quantitative comparison between the effects of a number of variables indicating strategic alternatives on firms' performance, this study offers unique insights. To wellknown strategic alternatives such as diversification, scale, cost leadership, locating in a cluster the strategic option of positioning in a network of firms is added. These variables can be argued to contribute both directly to firm performance, as well as indirectly by stimulating firm innovativeness. Findings we present allow for tentative comparison of the effects of choosing between the strategic alternatives for firm performance. There may be few other studies that offer such a comparison. ${ }^{7}$

Diversification does not help enhance firm performance nor does it improve firm innovativeness. Size of greenhouse as a proxy for economies of scale does allow the firm to be more innovative (mediation step 2, models 3 and 4), but this effect does not subsequently impact financial performance (mediation step 3, Model 5). Initially it appears that being part of a cluster enhances firm performance (model 1, 2 and 3). Once our network variable is introduced the impact of being part of a cluster becomes statically insignificant. Being part of a cluster does not make a firm more innovative once network position is taken into account. This seems to suggest that the network measure captures a number of effects that especially economic geographers since Alfred Marshall's Principles of Economics published in 1890 have assumed to be due to being located in a cluster (cf. Arkhan 2009). One’s network position is more important than one's physical location in a particular cluster (see Zaheer et al. 2010). Geographic clustering offers no solace, contrary to what the literature in economic geography argued clustering in regions would do. Firms may be co-located but not be in contact with each other and thus fail to exchange knowledge and experience - network contacts do not emerge as a matter of

\footnotetext{
${ }^{7}$ A search of the Web of Knowledge database using the combined keywords "firm strategy", "innovation”, and "firm performance", for instance, does not turn up results that empirically compare the contribution of different strategy options firms have for their innovative and ultimately financial performance.
} 
course (Dolfsma et al. 2009). This may explain why a recent review of the effect of regional clustering of firms does not seem to promote firm growth (Frenken et al. 2014). Production Cost actually has a negative and significant effect on financial performance and innovativeness, but these effects disappear when network variables are included. Being centrally positioned in a relevant network thus helps overcome cost disadvantages.

Among the control variables, Age of the owner has a consistently negative effect on firm financial performance but not on innovativeness. Age does not prevent the entrepreneur from innovating, but remarkably seems to prevent firm innovativeness from contributing to financial performance. The number of owners of a firm might affect the way in which a firm is governed, but that does not impact firm innovativeness or financial performance.

\section{Conclusion and Further Research}

We have included in our analysis a number of variables indicating classical strategic alternatives that firms can chose from. The strategic alternatives of cost structure, diversification, scale and location are classically believed to enhance firm performance. Our analysis suggests that strategic positioning in a network of relevant relations is more important than these classic strategic options a firm has at its disposal. Using domainspecific data that allows for genuine network analysis, we find that network position, rather than the well-known strategic options, strongly enhances a firm's financial performance. This effect is partially mediated through the contribution of a firm's position in a network to its innovativeness, however. This paper is the first to firmly establish this, quantitatively (cf. Uzzi and Lancaster 2003), signifying the importance of network positioning as a strategic tool (Ozcan and Eisenhardt 2009). Further research, possibly taking a longitudinal approach to more firmly establish causality in particular, including insights from Resource Based Theory (Sirmon et al. 2008), should confirm the generalizability of our findings. 


\section{References}

Aalbers, H.L. \& W. Dolfsma (2015) Innovation Networks. London \& New York: Routledge.

Ahuja, G. (2000) “Collaboration networks, structural holes and innovation” Administrative Science Quarterly 45: 425-455.

Allen, T.J. (1977) Managing the flow of technology. Cambridge MA: The MIT Press.

Arkhan, A.T. (2009) "Interfirm Knowledge Exchange and the Knowledge Creation Capability of Clusters" Academy of Management Review 34(4): 658-676.

Balkundi, P., Harrison, D.A. (2006) @Ties, leaders, and time in teams: strong inference about network structure's effects on team viability and performance@ Academy of Management Journal 49(1): 49-68.

Baron, R.M. and D.A. Kenny (1986) "The moderator-mediator variable distinction in social psychological research” Journal of Personality and Social Psychology 51: 1173-82.

Beckman, C.M. and P.R. Haunschild. (2002). "Network learning: The effects of partners' heterogeneity of experience on corporate acquisitions.” Administrative Science Quarterly 47: 92-124.

Belderbos, R., M. Carree and B. Lokshin (2004b) ‘Cooperative R\&D and Firm Performance’ Research Policy 33(10): 1477-1492.

Bono, J.E., Anderson, M.H. (2005) "The advice and influence networks of transformational leaders" Journal of Applied Psychology 90(6):1306-1314.

Borgatti, S.P. and R. Cross (2003) "A relational view of information seeking and learning in social networks” Management Science 49(4): 432-445.

Brass, D.J. (1984) "Being in the right place: a structural analysis of individual influence in an organization" Administrative Science Quarterly 29: 518-539

Burt, R.S. (1992) Structural holes. Cambridge: Harvard UP.

Burt, R.S. (2004) 'Structural Holes and Good Ideas' American Journal of Sociology, 110: 442-55.

Coleman, J.S., E. Katz and H. Menzel (1966) Medical Innovations. Indianapolis: Bobbs-Merrill.

Costenbader, E. and T.W. Valente (2003) "The stability of centrality measures when networks are sampled” Social Networks 25: 283-307.

Cross, R. and J.N. Cummings (2004) "Tie and network correlates of individual performance in knowledgeintensive work” Academy of Management Journal 47(6): 928-937.

Deshpandé, R., J.U. Farley and J. Webster (1993) "Corporate culture, customer orientation and innovativeness in Japanese firms” Journal of Marketing 57(1): $22-7$.

Dhanaraj, C. and A. Parkhe (2006) “Orchestrating Innovation Networks" Academy of Management Review 31(3): 659-669

Dittrich, K. and G. Duijsters (2007) "Networking as a means to strategic change: the case of open innovation in mobile telephony" Journal of Product Innovation Management 24(6): 510-521.

Dolfsma, W. and G. Van der Panne (2008) "Currents and sub-currents in innovation flows: Explaining innovativeness using new-product announcements” Research Policy 37(10): 1706-1716

Dolfsma, W., R. van der Eijk and A. Jolink (200) “On a Source of Social Capital: Gift Exchange” Journal of Business Ethics 89(3): 315-329.

Freeman, L.C. (1979) “Centrality in social networks: conceptual clarification” Social Networks 1: 215-239.

Freeman, C. (1991) "Networks of innovators” Research Policy 20: 499-514.

Frenken, K., E. Cefis, E. Stam (2014) "Industrial Dynamics and Clusters: A Survey” Regional Studies.

Geroski, P., S. Machin and J. Van Reenen (1993) “The profitability of innovating firms” RAND Journal of Economics 24(2): 198-211.

Gilsing, V., B. Nooteboom, W. Vanhaverbeke, G. Duysters and A. van den Oord (2008) “Network 
embeddedness and the exploration of novel technologies” Research Policy 37(10): 1717-31

Giuliani, E. and M. Bell (2005) "The micro-determinants of meso-level learning and innovation: evidence from a Chilean wine cluster” Research Policy 34(1): 47-68.

Granovetter, M.S. (1973) 'The Strength of Weak Ties’ American Journal of Sociology 78: 1360-1380.

Granstrand, O., P. Patel \& K. Pavitt (1997) "Multi-Technology Corporations: Why they have 'distributed rather than 'distinctive core' competences” California Management Review 39(3): 8-25.

Gulati, R., N. Nohria and A. Zaheer (2000) "Strategic Networks" Strategic Management Journal 21(3): 203-215.

Gulati, R. and M.C. Higgins (2003) "Which ties matter when? The contingent effects of interorganizational partnerships on IPO success" Strategic Management Journal 24: 127-144.

Hansen, M.T. (1999) “The Search-Transfer Problem” Administrative Science Quarterly 44(1): 82-111.

Human, S.E. and K.G. Provan (1997) "An Emergent Theory of Structure and Outcomes in Small-Firm Strategic Manufacturing Networks” Academy of Management Journal 40(2): 368-403.

Ibarra, H. (1993) “Network Centrality, Power and Innovation Involvement” Academy of Management Journal 36(3): 471-501.

Ingram, P. and Roberts, P. (2000) 'Friendship among Competitors in the Sydney Hotel Industry’ American Journal of Sociology 106(2): 387-423.

Ireland, R.D and M.A. Hitt (2005) "Achieving and maintaining strategic competitiveness in the 21st century” Academy of Management Executive 19(4): 63-77

Janowicz-Panjaitan M. and N. Noorderhaven (2008) "Formal and Informal Inter-organizational learning within strategic alliances" Research Policy 37: 1337-55.

Jansen, J.J.P., F.A.J.Van Den Bosch and H.W. Volberda (2006) “Exploratory Innovation, Exploitative Innovation, and Performance effects of organizational antecedents and environmental moderators" Management Science 52(11): 1661-1674.

Kijkuit, B. and J. van den Ende (2007) "The Organizational Life of an Idea: Integration Social Network, Creativity and Decision-Making Perspective” Journal of Management Studies 44(6)

Kleinknecht, A., K. van Montfort, and E. Brouwer (2002) “The non-trivial choice between innovation indicators” Economics of Innovation and New Technology 11: 109-121.

Kleinknecht, A.H. and R. Vergeer (2010) “Is wage-cost saving labour market deregulation a free lunch?” Journal of Post Keynesian Economics 33(2): 371-407.

Knoke D. and R.S. Burt (1983) "Prominence”. In: R.S. Burt and M. Minor (eds) Applied Network Analysis. Beverly Hills, CA: Sage pp.195-222.

Liao, T.-S and J. Rice (2010) "Innovation investment, market engagement and financial performance" Research Policy 39: 117-125.

Lundval, B.A. (1988) 'Innovation as an Inter-active process: From User-Producer Interaction to the National System of Innovation’ in: Technical Change and Economic Theory. Eds. Dosi, G. et al. London: Printer.

Malerba, F. (2002) “Sectoral Systems of Innovation and Production” Research Policy 31: 247-264.

Marsden, P.V. (2002) "Egocentric and sociocentric measures of network centrality” Social Networks 24: 407-422.

Mehra, A., Kilduff, M. and D.J. Brass (2001) "The social networks of high and low self-monitors: implications for workplace performance” Administrative Science Quarterly 46(1): 121-146.

Oh, H., G. Labianca and M.-H. Chungh (2006) “A Multilevel Model of Group Social Capital” Academy of Management Review 31(3): 569-582.

Ozcan, P. and K.M. Eisenhardt (2009) "Origin of alliance portfolios: Entrepreneurs, network strategies and firm performance" Academy of Management Journal 52(2): 246-279

Phelps, C.E. (2010) “A Longitudinal Study of the Influence of Alliance Network Structure and Composition on Firm Exploratory Innovation” Academy of Management Journal 53(4): 890-913. 
Reagans, R. and McEvily, B. (2003) ‘Network Structure and Knowledge Transfer’ Organization Science 13(3): 232-248

Reagans, R. and Zuckerman, E., (2001) "Networks, diversity and performance: The social capital of RandD units" Organization Science 12:502-517

Rodan, S. and C. Galunic (2004) 'More Than Network Structure: How Knowledge Heterogeneity Influences Managerial Performance and Innovativeness’ Strategic Management Journal 25: 541562.

Scott, J. (1991) Social network analyses. London: Sage.

Shaver, J.M. (1998) “Accounting for Endogeneity When Assessing Strategy Performance: Does entry mode choice affect FDI survival?” Management Science 44(4): 571-585.

Sirmon, D.G., S. Gove, M.A. Hitt (2008) "Resource Management in Dyadic Competitive Rivalry: The effects of resource bundling and deployment” Academy of Management Journal 51(5): 919-935.

Snijders, H., D. Jacobs and H. Vrolijk (2007) De Economische Kracht van Agrofood in Nederland. Den Haag: SMO.

Sobel, M.E. (1982) "Asymptotic confidence intervals for indirect effects in structural equation models" Sociological Methodology 13: 290-312.

Sparrowe, R.T., R.C. Liden, S.J. Wayne and M.L. Kraimer (2001) "Social Networks and the Performance of Individuals and Groups” Academy of Management Journal 44(2): 316-325.

Tsai, W. (2001), 'Knowledge transfer in intra-organizational networks' Academy of Management Review 44: 996-1004.

Tsai, W. and S. Ghosal (1998) ‘Social Capital and Value Creation’ Academy of Management Journal 41(4): 464-476.

Tushman, M.L. and Scanlan, T.J. (1981) "Boundary spanning individuals” Academy of Management Journal 24: 289-305.

Tushman, M.L. (1977) 'Special boundary roles in the innovation process’ Administrative Science Quarterly 22: 587-606.

Uzzi, B. (1997) 'Social Structure and competition in inter firm networks' Administrative Science Quarterly 42(1): 35-67.

Uzzi, B. and R. Lancaster (2003) "Relational Embeddedness and Learning: The case of bank loan managers and their clients” Management Science 49(4): 383-399.

Van der Panne, G. 2004 “Agglomeration externalities: Marshall versus Jacobs” Journal of Evolutionary Economics 14(5): 593-604.

Vanhaverbeke, W., V. Gilsing, B. Beerkens and G. Duysters (2009) "The Role of Alliance Network Redundancy in the Creation of Core and Non-core Technologies" Journal of Management Studies 46(2): 215-244.

Wasserman, S. and K. Faust (1994) Social network analysis. New York, NY: Cambridge UP.

Zaheer, A., R. Gözübüyük and H. Milanov (2010) "It’s the Connections: the network perspective in interorganizational research” Academy of Management Perspective 24(1): 62-77.

\section{Appendix: The Innovation - a controlled setting}

The horticultural industry has seen a range of innovations, both small and large in terms

of impact. Innovations that allow for control of soil temperature are particularly important

for Freesia growers to stimulate flower yield and production per $\mathrm{m}^{2}$, as being cost

efficient as well as timely in producing flowers is important. Soil temperature is an 
important variable for crop growth, and can, for instance, be manipulated by growth stage to impact crop development and quality. Soil temperature manipulation can also prevent bud development, resulting in vegetative crop without flowers. Based on expert consultation, a multi-stage innovation was selected to determine the innovativeness of horticulturalists. By pumping water through PE tubes, inserted into the soil, soil temperature can be manipulated. These complex systems to manipulate soil temperature are used by many growers of freesias, but to different extents, as the technology has developed and become more sophisticated over a number of years. Using the systems requires substantial training and experimentation. The first stage was first introduced in 1976, and the ninth and last stage was introduced in 1990. Growers need to experiment to learn how to use systems for soil temperature control. Significant investments of different kinds are required. The innovative systems to control ground temperature can be categorized according to the following stages: (1) Do you have a cooling installation, if so since when? (2) Do you use source cooling, if so since when? (3) Did you implement mechanical cooling, if so when? (4) Did you implement deep cooling, if so when? (5) Did you implement high cooling, if so when? (6) Did you implement temperature control by section, if so when? (7) Did you implement a temperature check control system that allows for regular, accurate temperature checks, and if so when? (8) Did you implement a temperature control system that allows for regular temperature and bulbs stage checks, and if so when? (9) Did you implement a control system that allows for cooling by growth stages, and if so when? The focal innovation in this study thus is a process innovation. As each implementing each stage requires careful and elaborate catering to local circumstances and an entrepreneur's strategic choices, we believe that this study should be considered a study of the effects of (process) innovation of firm performance, rather than one on technological adoption. 


\section{Appendix table}

Appendix: Means, Standard Deviations, Correlations

\begin{tabular}{|c|c|c|c|c|c|c|c|c|c|c|c|c|}
\hline & Variables & $\mathrm{n}$ & Mean & S.D. & 1 & 2 & 3 & 4 & 5 & 6 & 7 & 8 \\
\hline 1 & Age Owner & 63 & 46.0635 & 10.2089 & & & & & & & & \\
\hline 2 & $\begin{array}{l}\text { Governance } \\
\text { (\#Company owners) }\end{array}$ & 63 & 1.9206 & 0.80925 & 0.12 & & & & & & & \\
\hline 3 & Prod. Diff. & 63 & 0.4603 & 0.50243 & -0.084 & -0.067 & & & & & & \\
\hline 4 & Scale & 63 & 16,500 & $12,757.56$ & -0.211 & 0.178 & 0.208 & & & & & \\
\hline 5 & Cost & 61 & 285,068 & $2.13 E+05$ & 0.043 & -0.138 & 0.07 & 0.062 & & & & \\
\hline 6 & Cluster (1=cluster ) & 63 & 0.5714 & 0.49885 & 0.123 & 0.114 & -0.23 & 0.102 & 0.226 & & & \\
\hline 7 & Network centrality & 63 & 0.9365 & 1.53321 & -0.193 & 0.152 & 0.206 & $0.341^{* \star \star}$ & -0.165 & 0.154 & & \\
\hline 8 & Innovation & 63 & 108,5714 & 58,03245 & -0.037 & 0.152 & 0.144 & $0.433^{\star \star *}$ & -0.143 & 0.084 & $0.506^{\star \star *}$ & \\
\hline 9 & Revenue & 63 & 36,4604 & 15,92347 & $-0.274^{\star \star}$ & 0.144 & 0.089 & $0.261^{\star *}$ & -0.217 & 0.17 & $.603^{\star \star *}$ & $0.557^{\star \star \star}$ \\
\hline
\end{tabular}

Notes: 2-tailed; *, **, *** significant at the 0.10, 0.05, 0.01 levels. 